\title{
Song Texts, Theme and Roles of Vocal Music in Egungun Traditional Festival in Akesan, Awori land of Lagos State
}

\author{
Loko, Olugbenga Olanrewaju PhD
}

Department of Theatre Arts \& Music

Lagos State University Ojo, Lagos

morayostudio@yahoo.com

\section{Doi:10.5901/mjss.2014.v5n7p615}

\section{Abstract}

\begin{abstract}
Music plays vital roles in various aspects of celebrations among societies in Nigeria. In traditional festivals for example, music is an expression of the culture of the people. Akesan which is a town in Alimosho local Government Area of Lagos State is blessed with rich musical heritage. This paper examined the theme and content of music used in traditional festivals in Akesan, and the roles of song texts in the festival. The study relies on primary data collected through oral interviews conducted with indigenes, Egungun devotees, singers and drummers from Akesan in Lagos, south west Nigeria as well as music recordings and their transcriptions collected through participant observation method. While, we found that traditional festivals in this community has been buffeted by modernity through acculturation, the role and contextual performance of various song texts and their themes in this community provides some evidence that traditional festivals are still religiously observed and they are an integral part of the Awori community in Akeasn land.
\end{abstract}

Keywords: Akesan, Egungun, traditional, song texts, festival.

\section{Introduction}

Traditional festivals constitute the life wire of the socio-religious practices among the Awori of Lagos state (Ajetunmobi and Ishola, 1998). Both authors observed that the Awori in general are fully involved in varieties of traditional religious festivals which portray them as a society which values its cultural heritage.

Like other Yoruba sub group, different kinds of festivals pervade their cultural institutions among which is the Egungun festival particularly in Akesan land. It is an epitome of a society which values its cultural heritage. The festival is an acceptable general behaviour guarded by the norms and beliefs of its members. It is a festival of music and dance and is also used as period to pray for peace and prosperity in the communities. The just concluded Egungun festival took place from the month of May to the third week in July.

Many scholars have discussed the celebrations of traditional festivals in Nigeria. Among them are Ogunba (1978), Agordoh (1994), Okafor (1994), Hornby (1995), and Omibiyi (2005) to mention a few. Based on various studies on festivals, several definitions have emerged.

Ogunba (1975) defines festivals as the great artistic institution in traditional Africa. It is the season or period when people reinforce their belief in the worship of gods, the divinities and the deities. Hornby (1995) defines festival as a day or period of religious or other celebration. Omibiyi (2005) viewed festival as a periodic celebration in acknowledgement of blessings already received, and means of requesting for more blessings, protection and guidance from the creator through lesser gods and ancestors. Omojola (2006) observed among the various traditional communities in Nigeria that as a periodic celebration, festivals provide occasional forum for the people to pray for peace and prosperity, to offer sacrifices to the gods, to make atonement for the sins of the past as well to celebrate common ancestry.

From the above definitions, it can be deduced that festivals are periodic celebrations, illustrating among other things, historical event and appeasing of various gods for protection against enemies and evil forces.

\section{Objectives of the Study}

The objectives of this study correspond with the common goals of African musicology, which are scholarly and humanistic (Nketia 1985). The primary aim is to investigate roles of music in Egungun traditional festivals in Akesan. Specific objectives are to examine theme, content and the roles of song texts used in the traditional festival.

A transcription and content analysis of selected songs are made. In addition philosophy and practices, 
characteristic features of traditional festivals as well as perception of indigenes, visitors and devotees on the festivals are also provided.

\section{Significance of the Study}

Preliminary analysis of the literature available exposes the growing literature on the nature and performance of African traditional festivals. The practical concerns also emphasize the significance of studying the songs and musical instruments which are integral, interwoven and accompany these festivals. Therefore, this study is significant in that it provides documentation on the theme, content and the roles of songs in the Egungun traditional festival in Akesan land. In addition, the study also provides songs in staff notation, musical analysis of selected songs as well as interpretation of their texts. The study has the potential of stimulating further ethnomusicological studies along the same line in other traditional Nigerian and African communities.

\section{Methodology}

A multi-dimensional approach was explored. Two major aspects commonly associated with musicological research are adopted in the study. These are fieldwork (gathering of recordings and first-hand experience of musical life in a particular human culture) and deskwork which dealt mainly with literature search, transcriptions, analyses and drawing of conclusions which led finally to the writing of this paper. Using the content analysis technique, analysis of traditional egungun song texts, theme, and compositional elements in the vocal music which accompanies the festival at Akesan is provided. Akesan in Lagos state (a thriving urban centre of more than 10 million people) was selected because the researcher resides in the state. Data were collected through ethnographic techniques including in-depth interviews with key informants and participant observation as well as focus group discussions. Relevant information and performance practice which characterize the festival were collected and audio-visual recordings of performances were undertaken. Egungun devotees, singers and drummers were purposively interviewed to elicit information on their perception of the festival.

\section{Brief Historical Background on Akesan Land}

Akesan community is situated along Lasu/lba/Obadore/lgando road along lyana Ipaja axis under Alimosho local Government Area of Lagos State. The Awori in Akesan migrated from Oyo and their first settlement in Lagos was IsheriIle. In an oral interview with Chief Azeez Apalara the Are Olori Oje-president of all the heads of masquerade revealed that through oral transmission the founding fathers of Akesan land were Ominuaye and Aina Odofin among others who claimed to be children of Ogunfunminire the father of the Awori.

The early settlers in Akesan were engaged in various vocations among which are consultations of oracles, hunting, farming, and celebration of Egungun and the worship of a deity called Olofin. There are various titled chiefs such as Are Alagbaa, Oloje, Atoku Oje, lya Agan,Maje o baje, Akewe Okunrin, Akewe Obinrin who work in unity for the progress and development of the community. Till date nine Baales had ruled in Akesan land. However, the current Bale is Tajudeen Bayo Fagbohun, the head of all chiefs and Akesan community as a whole.

\subsection{Egungun in Akesan}

Ajetunmobi and Ishola (1998) opined that one of the major festivals among the Awori is Egungun, often referred to as Ara-Orun- visitor from heaven. Historically the Egungun in Akesan originated from Oyo. There are different kinds of Egungun (about thirty) and eight out of which were identified with some families in the community. The table below identifies various Egungun and their owners/families:

$\begin{array}{ll}\text { Name(s) of Egungun } & \text { Family (Owner) } \\ \text { Owolewa } & \text { General (Egun Ilu) } \\ \text { Oyadolu } & \text { Oya family } \\ \text { Eyeba } & \text { Odofin family } \\ \text { Ajo f'oyinbo } & \text { Idoyewo family } \\ \text { Modupe-Owo } & \text { Oduso family } \\ \text { Agbegijo } & \text { Osunba family } \\ \text { Obebe } & \text { Ajaju family } \\ \text { Ajogberu } & \text { Apalara family }\end{array}$




\section{Photo: Egungun Alago}

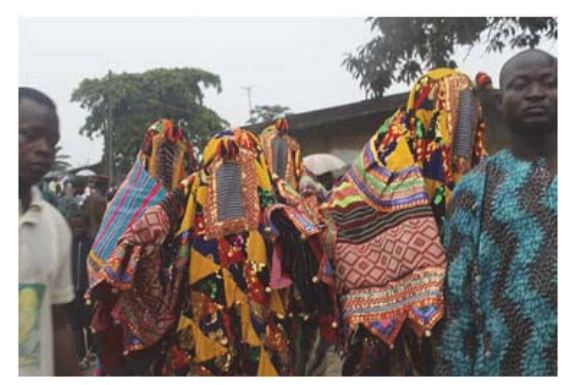

\subsubsection{Characteristic Features of Egungun Festival in Akesan}

Egungun is celebrated every ten years in Akesan, but the last one before the 2011 festival was celebrated 14 years ago. The festival celebration is organized in two sections; first is the cultic, which involves various rituals and worship session; and the second session is social strictly for entertainment.

The duration of the festival is three months. The preparation includes public announcement to create awareness. Movement is restricted to $6.00 \mathrm{am}$ and $10.00 \mathrm{pm}$ for the period of the festival and the pre festival rituals. Usually prior to the day of performance of each Egungun, the family that owns the Egungun usually entertain the community with food, drinks and music. Thus, proper preparations for the festival, especially the financial aspect, are made to ensure success of the periodic celebration.

The first day of the festival begins at 1.00 am with the appearance of Agan coming out from Egungun shrine called Igbale Egun. The Agan moves round the community praying for every individual and the community as a whole, this is done till around $4.00 \mathrm{a} . \mathrm{m}$ in the morning when he goes back to the shrine. By 10.00am in the morning the indigenes sing round the community, creating awareness for the commencement of the festival. On the second day the Ajeran masquerade parades the community from 9.00 am to 12.00 noon. After which the head of the masquerade (Olori Egun) appears publicly with prayers, followed by other masquerades. The costume of Olori Egun is very long that some of the accompanying masquerades have to hold the tail during procession.

On the first Sunday of the festival, Omolewa masquerade entertains at Esa (designated arena) where the community usually congregate for the Egungun festival. The head of masquerade also comes on first Sunday to pay homage at Esa after which he moves straight to Igbale Egun, at this period its costume will be left on the ground without being held by masquerade whereby he walks majestically. On the second Sunday of the festival, Oyadolu masquerade appears in public and then entertains the community at Esa. This entertainment goes on till the last day of the festival when Ajegberu the masquerade of Apalara family entertain the community at Esa.

One common feature among the masquerades at Akesan particularly in the entertainment arena is the display of magical powers in which the Egungun change from the human form to animal or plant form. The magical performances usually culminate as climax of the festival. Since the inception of Egungun festival in Akesan community, Oyadolu (Egungun) was the only known magic performing masquerade. However, recent events revealed that Eyeba, Ajof'oyinbo and Opeowo are also capable of displaying magic. These Egungun changed from the human form to adopt the form of a wild animal such as lion. They also took the form of wooden utensil.

Photo: Egungun Obebe displaying

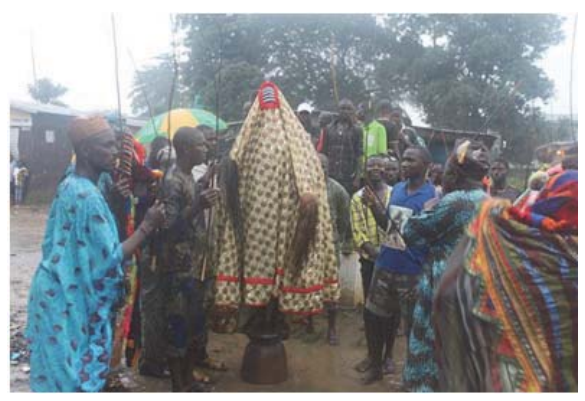


Egungun is believed to be capable of bringing children to the world and healing them of all their ailments when they are sick, hence they are known as Olomowewe. Canes (atori) are used by Egungun devotees and followers to express their joy, happiness and to cheer one another up during the festival. According to one of the devotees of Egungun Ismaila Aberuagba, the secretary of Oje Akesan, they only use the cane on people they know and it is not painful.

\subsection{Roles of Music in Egungun Festival of Akesan}

Traditional folk songs and indigenous-derived performance practices have continued to distinguish the musical content of Yoruba traditional festivals. Music (both vocal and instrumental) therefore, plays a very significant role in traditional festivals in Akesan land. It is the music that makes the festival interesting; it is very basic to the festival because every activity revolves around it.

Given the focus of this paper is on the role of music in traditional festivals in Akesan land. Using content analysis technique, some selected song texts were examined and analysed. It further discussed the roles of such songs used in the Egungun festival among the indigenes of Akesan.

The roles of music in festivals have been discussed by many researchers; Nketia (1974) and Vidal (1979) among others. Nketia(1974) explained that festivals provide opportunities for sharing creative experiences. Vidal (1979) pointed out a number of roles played by music in festivals, such as providing signal and publicity. He explained further that music also provides evocative and satirical role.

Aluede (2008) in his studies of therapeutic music of the lyayi society pointed that in understanding what lyayi music means is to have a firm grasp of not just its texts as poems but also their functions and relevance in services. He further noted that content and context analysis of songs give a more accurate idea of their use. All the songs used during Egungun festival depict the kind of ceremony going at that particular time. Song texts are the principal determinant of selecting appropriate songs for the festival.

The Egungun festival of Akesan employs different but specific music for various activities in this festival. For example there are specific music used for rituals, creating awareness, public appearance, therapeutic and entertainment. All these roles are discussed under analysis of songs used in the Egungun festival.

Traditional drums of various sizes and shapes are used during the festival. They include gangan, bata and bembe. Others are sekere, and agogo, however, drumming was dominant. These musical instruments are used to accompany songs, their roles in the festival are enormous, they make the entertainment period enjoyable, members of the community sing and dance vigorously to the rhythmic sound of the musical instruments expressing their inner experience and emotions.

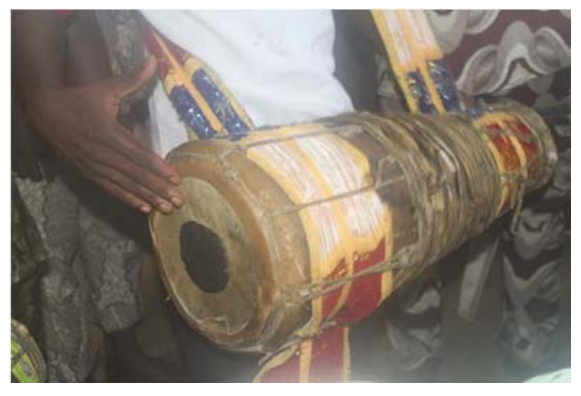

Photo: A member of bata ensemble

The preceding section discussed the texts translation and meaning. This section examined the structure of some selected songs vis-à-vis tonalities, scale patterns, melodic contours, meter, and form.

\section{Textual Analysis}

Text:

Song 1. Iku ko ni yale wa o e

Arun oni yale wa o e

Mo ti dele, moti dele, Oloje 


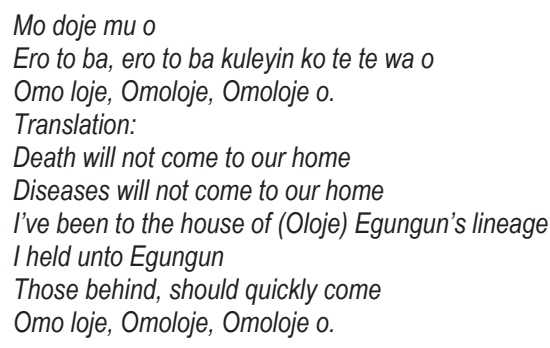

Iku o ni yale wa o

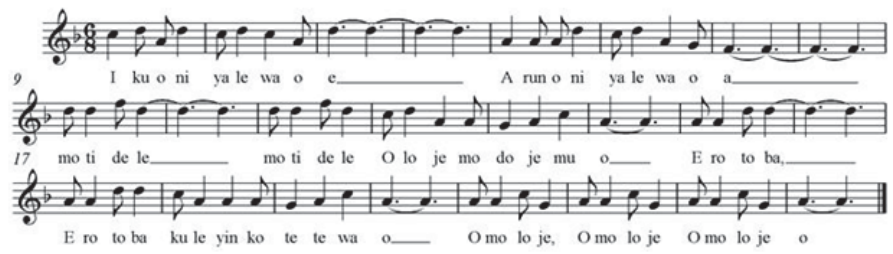

This is a prayerful song used by devotees to pray during the festival against death and diseases. Also using it to invite members of the community to come and enjoy what they have experienced in the cult especially the Egungun lineage. The song is rendered joyfully and gracefully.

Text:

Song 2. Ewa wo ese Awo wa o

Ewa wo ese Awo wa

Eee, Ee ara, Ewa wo ese Awo wa

Translation:

Come and witness our sacred stepping

Come and witness our sacred stepping

Eh, Eh display

Come and witness our sacred stepping

E wa wo Ese Awo wa o

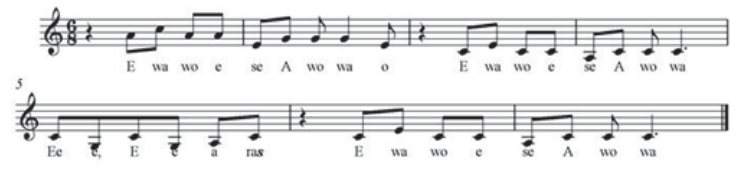

This song above is used during the festival by Egungun devotees when the Egungun is dancing and invites members of the community (mainly the audience) to come and witness the dance steps (its performance) of the Egungun. During this period, the Egungun is happy with the hailing and singing; this makes the Egungun to display varied dancing styles

Text:

Song 3.Etutu tase Kadura wa gba 0.

Etutu tase Kadura wa gba o

Kalowo, kabimo nilu Akesan o

Etutu tase Kadura wa gba o

Translation:

The sacrifice we offer, let our prayers be answered The sacrifice we offer, let our prayers be answered May we prosper and be fruitful in Akesan Land

The sacrifice we offer, let our prayers be answered 
Iho ho lo o wa o

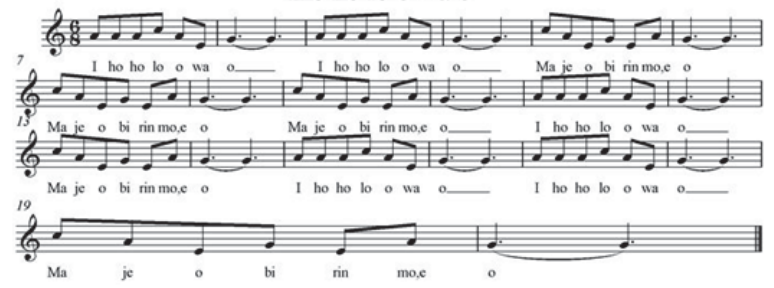

Usually during Egungun festival, many sacrifices are offered with prayers for individuals and the community as a whole. Most often, this song is rendered by the Egungun and devotees in procession round the community the day after the Agan's appearance and prayer for the community.

Text:

Song 4. Iho ho loo wa o, iho ho loo wa o

Maje obirin o mo e 0

Maje obirin o mo e o, Maje obirin o mo e o

Maje obirin o mo e o, Iho ho loo wa o,

Maje obirin o mo e o, Iho ho loo wa o,

Iho ho loo wa o, Maje obirin o mo e o.

Translation:

You're naked, you're naked

Don't allow woman to recognise you

Don't allow woman to recognise you

Don't allow woman to recognise you

You're naked, don't allow woman to recognise you

This is a warning song for the Egungun by devotees. When Egungun displays magical power or dances vigorously, especially when changing from one form to the other, the song is used to warn him to be careful of how he changes, so that he doesn't expose his identity and also show his nakedness to women around the performance arena.

Text:

Song 5.Won se ba' kesan maja- Oba lo ba wa se

Won se ba' kesan maja- Oba lo ba wa se

lja osi mo, ko so te mo

lja osi mo, ko so te mo

Won se ba' kesan maja- Oba lo ba wa se

\section{Translation:}

They taught there will be quarrel in Akesan

They taught there will be quarrel in Akesan

It was God that helped us

No more quarrels, no more rivalry

They taught there will be quarrel in Akesan

It was God that helped us.

In the early years, Egungun festivals were characterised by quarrels and rivalry. The song is rendered at the climax of the festival, to thank God the Almighty for the success of the festival (particularly after Bale's plea to all and sundry to maintain peace during the period of the festival). Oba in the song represents God

The song is in call and response form.

Text:

Song 6.Egun ile wa ko sako seni kan

Osa ile wa ko sako seni kan 
Efun omo laye, efun omo laye

Efun omo laye, komo ose le Baba re o

Translation:

Our Egungun is not proud to anybody

Our deity is not proud to anybody

Give the child a chance; give the child a chance

Give the child a chance to perform the Egungun rite.

The song above is used to portray Egungun's humility.

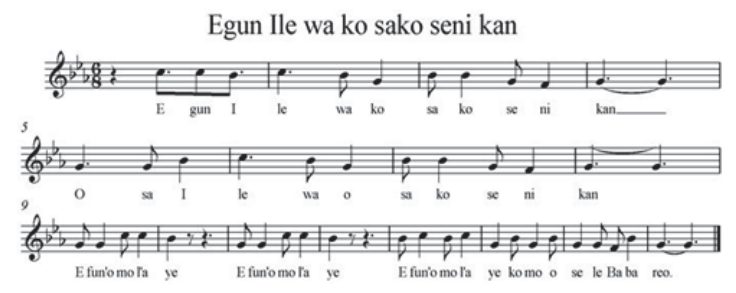

\section{Form and Structure}

It is generally accepted that traditional African music is largely antiphonal where a leader commences an antecedent to which a larger chorus responds. The structural form of the selected songs is predominantly call and response, which characterises all forms of performance practices mostly found in African vocal music. The songs are presented in short simple phrases and fitted together to make a meaningful whole.

Two varieties of call and response antiphony (Call and response proper, and Call and Refrain) were present in songs used in Akesan Egungun festival. Call and response proper occurs when an antecedent by the soloist is repeated by the larger group. The second type of call and response antiphony is also present in the same piece of music. At the chorus section, the lead singer sings with the other members of the singing group and audience responds. Also there are songs such as oriki that are in through composed form.

\section{Structural Analysis}

All the songs notated are in Compound duple time signature (six quavers in each bar). In song 1, I have used the key signature of $\mathrm{F}$ major and the scale mode is hexatonic and the song used six tones of the scale. While in Song 2, I used a key signature of $\mathrm{C}$ major and the scale mode is pentatonic minor. The melody made use of four tones of the scale. Song 3 has a key signature of $\mathrm{G}$ major and the scale mode is hexatonic, only six tones of the scale were employed. The key signature used in Song 4 is $\mathbf{C}$ major and the scale mode is pentatonic minor employing only four tones of the scale. In Song 6 the key signature I have used is the $E$ flat major and its scale mode is pentatonic minor employing four tones of the scale.

\subsection{Intervallic Structure of the Melodies}

All the songs; $1,2,3,4$, and 6 consists of intervals of full and half tones as evidenced in a number of bars in all the above songs. Intervallic jump of perfect $4^{\text {th }}$, 3rds, stepwise melodic movements and some static notes characteristic of African melodies are maintained in all the songs notated.

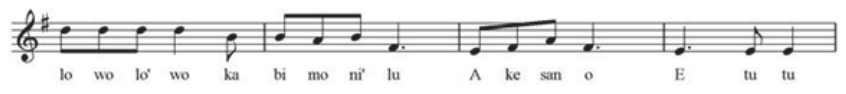

\subsection{Rhythmical Structure of the Melodies}

To provide interesting metrical organisation, short to long (quaver to crotchet); long to long (dotted crotchet to dotted crotchet); short to short (quaver to quaver); and the use of Hemiola (crotchet, crotchet, crotchet) durational notes serves 
as rhythmical basis of the songs.

\section{Conclusion}

From the above study, music plays significant role in the Egungun festival of Akesan. It is the vehicle used to pervade culture, which is manifested in the festival. The roles of vocal songs in the festivals are easily identified through their texts. Music is used to announce the beginning and the end of the festival, offer supplications to the gods. It is also used to gain insight into the culture of the community.

Unfortunately, derogatory attitude of the present generation towards our culture has sent many of our music genres into total oblivion thus many songs which accompany traditional festivals have been lost to posterity without proper documentation and preservation. It is hoped that more research would be embarked upon by music scholars on the analysis and documentation of songs used in various traditional religious festivals.

\section{References}

Ajetunmobi R.O, Ishola H.T.K, 1998. Festivals in Aworiland: The Awori of Lagos State : Adeniran Ogunsanya College of Education, Ottoljanikin Press Lagos.

Ogunba O, 1978. Traditional African Festival Drama in Theatre in Africa. Edited by Ogunba, O and Irele, A: University press Ibadan Agordoh A.A, 1994. The significance of Festivals in Africa. Studies in African Music. Ghana: How New Age Publications.

Okafor R.C, 1994. Festivals as purveyors of information in Igbo Culture. In Akumah, E. Emeka, L.N \& Okafor R.C (Eds.). Nigerian peoples and culture: Enugu State University Press.

Hornby A.S, 1995. Oxford Advanced learner's Dictionary of Current English. New York: Oxford University Press.

Omibiyi Obidike, 2005. Femininity in Traditional Festivals: The place of Women in Sango Worship performance. Association of Nigerian Musicologists, 1 vol. 2 29-44.

Omojola Bode, 2006. Popular Music in Western Nigeria: Theme, Style and Patronage Systems: Ibadan Gold Press Ltd.

Nketia J.H.K. 1974. The Music of Africa. New York: W.W. Norton and Company Inc.

Nketia J.H.K. 1985. Integrating objectivity and experience in ethnomusicological studies. The World of Music,: Vol. 27. 3-19.

Vidal Tunji, 1979. The Role and Function of Music at Yoruba Festivals. African Musicology: Current Trends. A Festschrift in honour of J.H.K Nketia, 56-64.

Aluede Charles O, 2008. Music as Therapy by the lyayi Society of Edo State, Nigeria. PhD Thesis. University of Ibadan, Institute of African Studies Ibadan. 